\title{
Upper tropospheric water vapour and its interaction with cirrus clouds as seen from IAGOS long-term routine in-situ observations
}

DOI:

10.1039/c7fd00006e

\section{Document Version}

Accepted author manuscript

Link to publication record in Manchester Research Explorer

Citation for published version (APA):

Petzold, A., Krämer, M., Neis, P., Rolf, C., Rohs, S., Berkes, F., Smit, H. G. J., Gallagher, M., Beswick, K., Lloyd, G., Baumgardner, D., Spichtinger, P., Nédélec, P., Ebert, V., Buchholz, B., Riese, M., \& Wahner, A. (2017). Upper tropospheric water vapour and its interaction with cirrus clouds as seen from IAGOS long-term routine in-situ observations. Faraday Discussions, 200, 229-249. https://doi.org/10.1039/c7fd00006e

\section{Published in:}

Faraday Discussions

\section{Citing this paper}

Please note that where the full-text provided on Manchester Research Explorer is the Author Accepted Manuscript or Proof version this may differ from the final Published version. If citing, it is advised that you check and use the publisher's definitive version.

\section{General rights}

Copyright and moral rights for the publications made accessible in the Research Explorer are retained by the authors and/or other copyright owners and it is a condition of accessing publications that users recognise and abide by the legal requirements associated with these rights.

\section{Takedown policy}

If you believe that this document breaches copyright please refer to the University of Manchester's Takedown Procedures [http://man.ac.uk/04Y6Bo] or contact uml.scholarlycommunications@manchester.ac.uk providing relevant details, so we can investigate your claim.

\section{OPEN ACCESS}




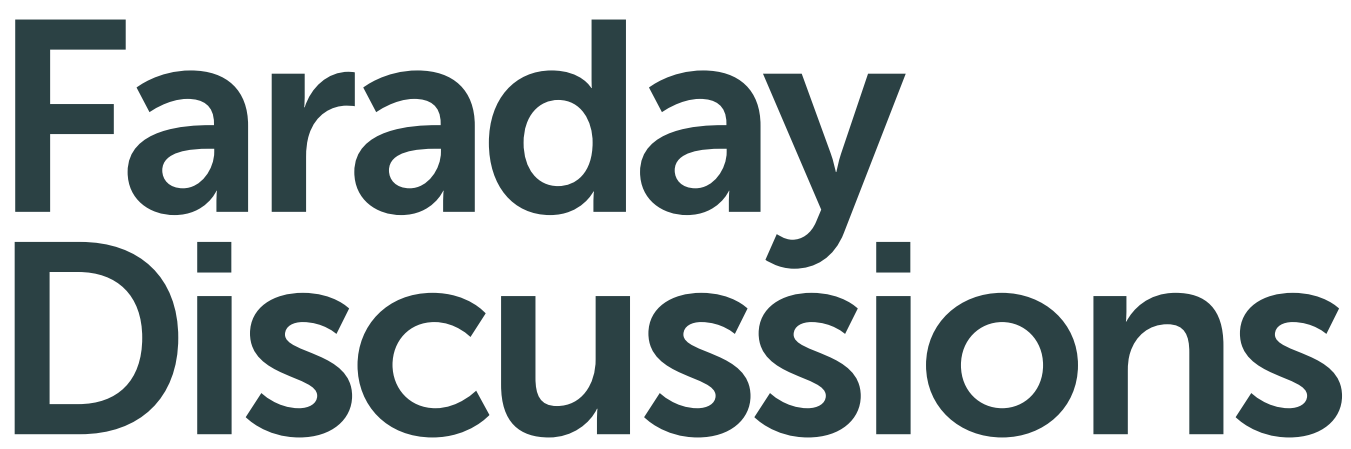

\section{Accepted Manuscript}

This manuscript will be presented and discussed at a forthcoming Faraday Discussion meeting.

All delegates can contribute to the discussion which will be included in the final volume.

Register now to attend! Full details of all upcoming meetings: http://rsc.li/fd-upcoming-meetings

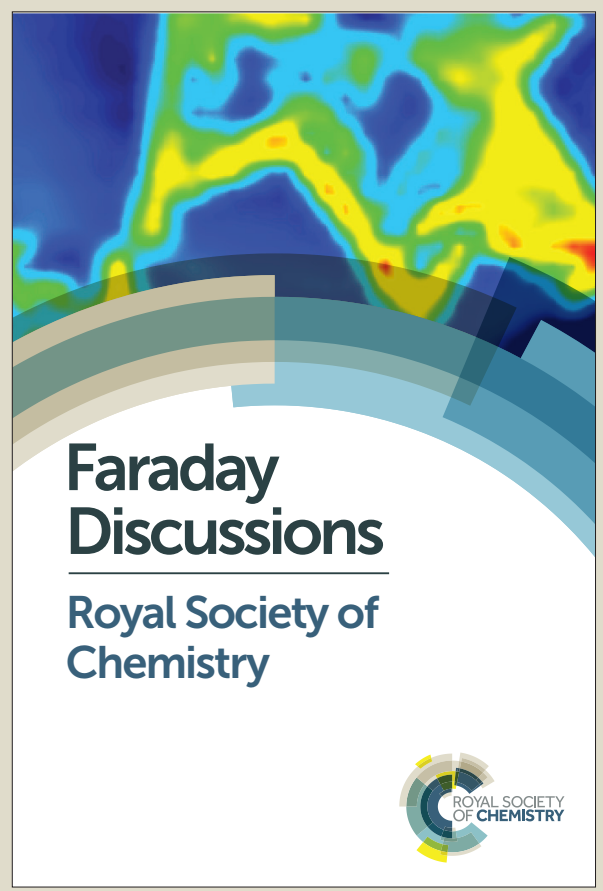

This is an Accepted Manuscript, which has been through the Royal Society of Chemistry peer review process and has been accepted for publication.

Accepted Manuscripts are published online shortly after acceptance, before technical editing, formatting and proof reading. Using this free service, authors can make their results available to the community, in citable form, before we publish the edited article. We will replace this Accepted Manuscript with the edited and formatted Advance Article as soon as it is available.

You can find more information about Accepted Manuscripts in the Information for Authors.

Please note that technical editing may introduce minor changes to the text and/or graphics, which may alter content. The journal's standard Terms \& Conditions and the Ethical guidelines still apply. In no event shall the Royal Society of Chemistry be held responsible for any errors or omissions in this Accepted Manuscript or any consequences arising from the use of any information it contains.

This article can be cited before page numbers have been issued, to do this please use: A. Petzold, M. Krämer, P. Neis, C. Rolf, S. Rohs, F. Berkes, H. G. J. Smit, M. Gallagher, K. Beswick, G. Lloyd, D. Baumgardner, P. Spichtinger, P. Nédélec, V. Ebert, B. Buchholz, M. Riese and A. Wahner, Faraday Discuss., 2017, DOI: 10.1039/C7FD00006E. 


\title{
Upper tropospheric water vapour and its interaction with cirrus clouds as seen from IAGOS long- term routine in-situ observations
}

Andreas Petzold ${ }^{a}{ }^{,}$, Martina Krämer ${ }^{b}$, Patrick Neis ${ }^{a, e}$, Christian Rolf ${ }^{b}$, Susanne Rohs ${ }^{a}$, Florian Berkes ${ }^{a}$, Herman G.J. Smit ${ }^{a}$, Martin Gallagher ${ }^{c}$, Karl Beswick, Gary Lloyd ${ }^{c}$, Darrel Baumgardner ${ }^{d}$, Peter Spichtinger ${ }^{\mathrm{e}}$, Philippe Nédélec ${ }^{\mathrm{f}}$, Volker Ebert ${ }^{\mathrm{g}}{ }^{\mathrm{h}}$, Bernhard Buchhol $\mathrm{z}^{\mathrm{g}}, \mathrm{h}$, Martin Riese $\mathrm{e}^{\mathrm{b}}$, Andreas Wahner $^{\mathrm{a}}$

${ }^{a}$ Forschungszentrum Jülich, IEK-8 Troposphere, Jülich, Germany

${ }^{\mathrm{b}}$ Forschungszentrum Jülich, IEK-7 Stratosphere, Jülich, Germany

' University of Manchester, Manchester, UK

${ }^{\mathrm{d}}$ Droplet Measurement Technologies, Boulder, USA

${ }^{\mathrm{e}}$ Institute for Atmospheric Physics, Johannes Gutenberg University, Mainz, Germany

${ }^{f}$ Laboratoire d'Aérologie, CNRS, Toulouse, France

${ }^{g}$ Physikalisch-Technische Bundesanstalt, Braunschweig, Germany

${ }^{\mathrm{h}}$ Technische Universität Darmstadt, Institute of Reactive Flows and Diagnostics, RSM, Analytical Photonics Group, Darmstadt, Germany

Corresponding author: Andreas Petzold, a.petzold@fz-juelich.de

\begin{abstract}
IAGOS (In-service Aircraft for a Global Observing System) performs long-term routine in-situ observations of atmospheric chemical composition $\left(\mathrm{O}_{3}, \mathrm{CO}, \mathrm{NO}_{x}, \mathrm{NO}_{y}, \mathrm{CO}_{2}, \mathrm{CH}_{4}\right)$, water vapour, aerosols, clouds, and temperature on a global scale by operating compact instruments on board of passenger aircraft. The unique characteristics of the IAGOS data set originate from the global scale sampling on air traffic routes with similar instrumentation such that the observations are truly comparable and well suited for atmospheric research on a statistical basis. Here, we present the analysis of 15 months of simultaneous observations of relative humidity with respect to ice $\left(\mathrm{RH}_{\text {ice }}\right)$ and ice crystal number concentration in cirrus $\left(\mathrm{N}_{\text {ice }}\right)$ from July 2014 to October 2015. The joint data set of 360 hours of $\mathrm{RH}_{\text {ice }}-\mathrm{N}_{\text {ice }}$ observations in the global upper troposphere and tropopause region is analysed with respect to the in-cloud distribution of $\mathrm{RH}_{\text {ice }}$ and related cirrus properties. The majority of the observed cirrus is thin with $\mathrm{N}_{\text {ice }}<0.1 \mathrm{~cm}^{-3}$. The respective fractions of all cloud observations range from $90 \%$ over the mid-latitude North Atlantic Ocean and the Eurasian Continent to $67 \%$ over the subtropical and tropical Pacific Ocean. The in-cloud $\mathrm{RH}_{\text {ice }}$ distributions do not depend on the geographical region of sampling. Types of cirrus origin (in situ origin, liquid origin) are inferred for different $\mathrm{N}_{\text {ice }}$ regimes and geographical regions. Most importantly, we found that in-cloud $\mathrm{RH}_{\text {ice }}$ shows a strong correlation to $\mathrm{N}_{\text {ice }}$ with slightly supersaturated dynamic equilibrium $\mathrm{RH}_{\text {ice }}$ associated with higher $\mathrm{N}_{\text {ice }}$ values in stronger updrafts.
\end{abstract}




\section{Introduction}

The radiative impact of cirrus clouds is one of the largest sources of uncertainty in the Earth's energy balance, and even fundamental details of ice cloud processes are still poorly understood ${ }^{1}$. Model studies demonstrate that the magnitude and even sign of the net effect depend crucially on microphysical properties of ice crystals, e.g. size or shape ${ }^{2,3}$, and ice-supersaturation in clouds ${ }^{1,4,5}$. Besides its close link to cirrus formation and lifecycle, understanding the processes which control the distribution of water vapour as one of the most important climate-active gases in Earth's atmosphere is of high relevance for predicting future climate in the Anthropocene ${ }^{6,7}$. Upper tropospheric humidity is also relevant for the major anthropogenic impact on ice clouds via aviation-induced cirrus, which form in ice-supersaturated regions ${ }^{8}$.

One particular focus of current research on cirrus concerns the distribution of relative humidity with respect to ice $\left(\mathrm{RH}_{\text {ice }}\right)$ in clear sky and in cirrus clouds since ice supersaturation $\left(\mathrm{RH}_{\text {ice }}>100 \%\right)$ controls the relevant processes of ice nucleation (homogeneous, heterogeneous) ${ }^{9-11}$ and the further cloud evolution. Moreover, the level of ice supersaturation in clouds in combination with ice crystal number concentrations might allow the determination of certain cirrus formation types (in-situ origin, liquid origin) $)^{11-13}$. With current measurement technology, however, the parameters relevant for the investigation of cirrus formation processes are accessible only in dedicated field studies using highly sophisticated instrumentation for the measurement of water vapour and cloud microphysics.

The investigation of cirrus cloud evolution and lifetime as well as upper tropospheric humidity on a global scale relies on different experimental approaches. Global coverage of observations is targeted by using space-borne observation systems like the A-Train ${ }^{14-16}$, infrared sounder ${ }^{17-19}$ or aircraft-based observations from routine in-situ measurements of upper tropospheric humidity aboard passenger aircraft in the research programmes MOZAIC ${ }^{20-22}$ or CARIBIC ${ }^{23}$. Microphysical processes in cirrus clouds have been approached by large-scale field experiments of global dimension like INCA ${ }^{24}$ or HIPPO $^{25,26}$, or by a combined analysis of a global data set of in-situ observations ${ }^{11,27,28}$.

In-situ observations of cirrus properties in dedicated field experiments provide detailed insights into physical processes and microphysical properties of cirrus clouds; however, they are not suitable for delivering a more global view on cirrus formation and lifecycle in a statistical sense, including seasonal aspects. On the other hand, satellite-based remote sensing studies provide the global view on cirrus, but require in-situ evaluation of the obtained results. Since cirrus and ice-supersaturated layers are usually very thin in vertical extension ${ }^{14}$, in situ measurements are urgently needed, since the satellite view does not provide sufficient vertical resolution. The most promising way forward to bridge the gap between the global view from space and the detailed in-situ approach is the operation of compact instruments on board of passenger aircraft which fly globally and conduct routine in-situ observations of the required properties.

This approach was implemented and recently became fully operational as the European research infrastructure IAGOS (In-service Aircraft for a Global Observing System; www.iagos.org) where IAGOS-CORE continues and extends the predecessor programme MOZAIC (Measurement of ozone and water vapour by Airbus in-service aircraft) ${ }^{29}$. As part of IAGOS scheduled passenger aircraft continuously collect data on atmospheric chemical composition $\left(\mathrm{O}_{3}, \mathrm{CO}, \mathrm{NO}_{x}, \mathrm{NO}_{y}, \mathrm{CO}_{2}, \mathrm{CH}_{4}\right)$, water vapour, aerosols, clouds and temperature on a global scale ${ }^{30}$. The unique characteristics of the IAGOS data set relates to the global scale sampling with similar instrumentation such that the observations 
are truly comparable. Since commercial aircraft fly almost similar air traffic routes independent of season and weather the collected data are well suited for atmospheric research on a statistical basis.

The MOZAIC data was used for first statistical investigations of ice supersaturation in the tropopause region ${ }^{20-22,31}$. With the integration of the Backscatter Cloud Probe (BCP) ${ }^{32,33}$ into the IAGOS instrumentation and the in-depth evaluation of the operational IAGOS Capacitive Hygrometer (ICH) ${ }^{34}$, a unique global scale data set of in-cloud and cloud-free observations of $\mathrm{RH}_{\text {ice }}$ and ice crystal number concentration in cirrus $\left(\mathrm{N}_{\text {ice }}\right.$ ) is developing. A first study on global cirrus properties from IAGOS BCP data has already been published ${ }^{33}$.

Here we present the joint analysis of 15 months of $\mathrm{RH}_{\text {ice }}-\mathrm{N}_{\text {ice }}$ observations aboard IAGOS-CORE aircraft from July 2014 to October 2015, for which quality-controlled final data are available. The additional value of merging the data sets is put into the focus of our data analysis, namely the possibility to study the distribution of relative humidity in cirrus clouds and in clear sky and to investigate potential relations between $\mathrm{RH}_{\text {ice }}$ and $\mathrm{N}_{\text {ice }}$. So far, there is no other global data set available which permits this kind of research.

\section{Methods and Data Selection}

\subsection{Instrumentation}

The $\mathrm{RH}_{\text {ice }}-\mathrm{N}_{\text {ice }}$ data set originates from compact sensors for relative humidity and cloud particles, $\mathrm{ICH}$ and $\mathrm{BCP}$, respectively, which are part of the IAGOS-CORE instrumentation and mounted as shown in Figure 1. Both sensors measure directly in the air passing by outside the aircraft skin. Sensor details are described elsewhere ${ }^{32-35}$ whereas a brief description is provided in the following.

The BCP is an optical particle spectrometer that detects the light scattered in a backward cone by individual hydrometeors that pass through the centre of focus of a $650 \mathrm{~nm}$ wavelength beam generated by a diode laser. The fraction of light that is scattered backward at a solid angle of 144$156^{\circ}$ is collected by a set of lenses that are located behind the window in the aircraft skin. The detected light pulses serve as count signals for cloud particles passing through the laser sampling area. The cloud particle number concentration is then calculated from the sampling area times the true air speed of the aircraft. The BCP detection particle size range from 5-75 $\mu \mathrm{m}$ in diameter ${ }^{32,33}$, however, does not cover the full size spectrum of ice crystals which may be as large as $\approx 1 \mathrm{~mm}$ in diameter in cirrus clouds. Because of its mounting position in the cockpit section where the aircraft body diameter is already close to its maximum size and with no leading edges of instruments or inlets upstream the detection window for droplets or crystals to impact and break, the BCP is considered almost unaffected by ice crystal shattering ${ }^{32}$.

The ICH is a compact airborne humidity sensing device based on capacitive sensors of type Vaisala HUMICAP ${ }^{\circledR} \mathrm{H}$ combined with a platinum resistance sensor Pt100 for the direct measurement of the temperature close to the humidity sensing element. The latter is composed of a hydroactive polymer film as dielectric medium whose capacitance depends on the relative humidity of the surrounding air. The hygrometer is mounted inside a standard Rosemount inlet housing. 


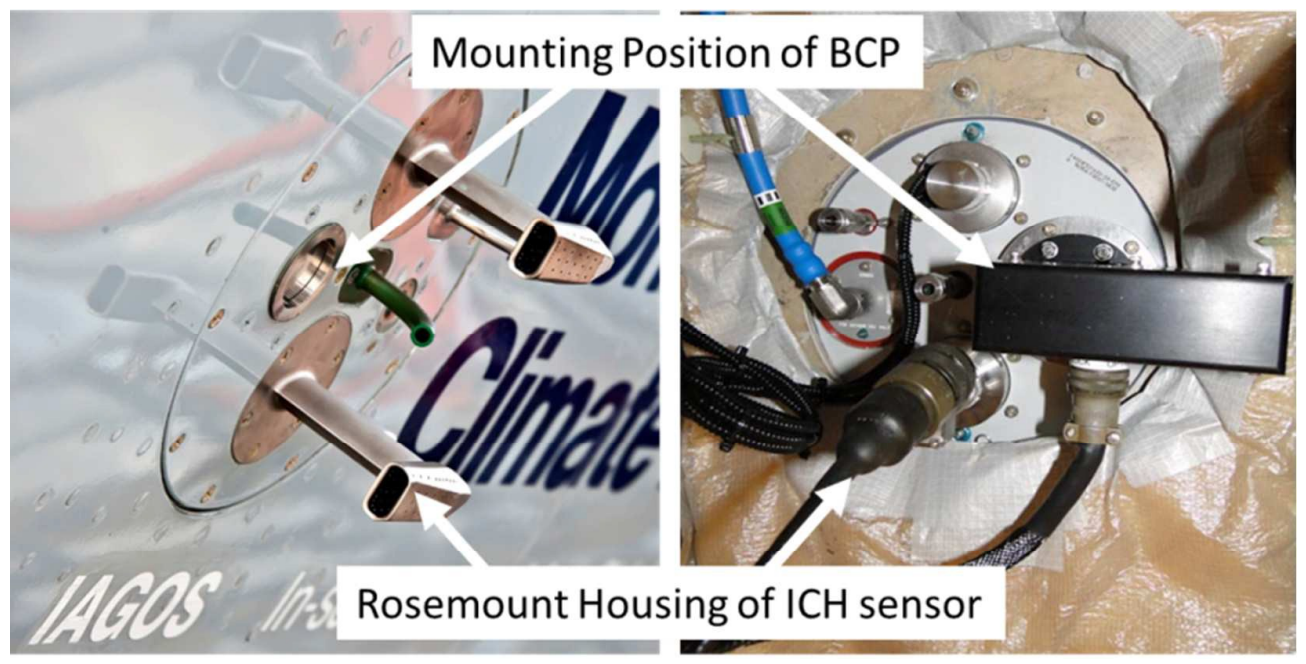

Figure 1. Positions of IAGOS Capacitive Hygrometer ICH and Backscatter Cloud Probe BCP on the IAGOS inlet flange (photographs by courtesy of Lufthansa Archive).

The basic principles of the $\mathrm{ICH}$ including sensor calibration and the procedures for the determination of the ambient air temperature $T_{\text {amb }}$ from the sensor temperature $T_{\text {sensor }}$ are described elsewhere ${ }^{22,35}$. The measured capacitance is converted into relative humidity with respect to liquid water $\left(\mathrm{RH}_{\text {liquid }}\right)$ based on the sensor calibrations performed before and after their deployment on the aircraft. The $1 \sigma$ - uncertainty of the $\mathrm{ICH}$ is quantified as $5 \% \mathrm{RH}_{\text {liquid }}{ }^{22}$ with its minimum detectable water vapour mixing ratio being about $10 \mathrm{ppmv}^{36}$. Given the uncertainty range of this method, negative values of $\mathrm{RH}_{\text {ice }}$ are accepted within the $3 \sigma$ range of $15 \% \mathrm{RH}_{\text {liquid }}$ to avoid biasing effects at low humidity. Finally, $\mathrm{RH}_{\text {ice }}$ is calculated from $\mathrm{RH}_{\text {liquid }}$ via the conversion equations by Sonntag ${ }^{37}$.

\subsection{Data Selection}

Data suitable for our study are selected based on a set of criteria which ensure the focus of the data analysis:

- pressure $p<350 \mathrm{hPa}$ to limit data to cruise altitude $>8.1 \mathrm{~km}$ at standard atmosphere conditions;

- $\mathrm{T}_{\mathrm{amb}}<233 \mathrm{~K}$ (temperature threshold for spontaneous freezing of water droplets) to exclude data during coexistence of supercooled liquid water droplets;

- $\mathrm{T}_{\text {sensor }}>233 \mathrm{~K}$ (minimum sensor calibration temperature) to restrict the data analysis to the calibrated range of the $\mathrm{ICH}$.

For this study, the 6-hourly output from the ECMWF ERA-Interim Reanalysis ${ }^{38}$ were interpolated onto a $1^{\circ} \times 1^{\circ}$ horizontal grid, and on 60 vertical levels of constant pressure and potential temperature ${ }^{39}$. With this, the pressure of the thermal tropopause was calculated based on the WMO criteria ${ }^{40}$ and linearly interpolated (longitude, latitude, pressure, time) onto each flight track with $4 \mathrm{~s}$ resolution ${ }^{39}$. Only the data below the thermal tropopause were considered to focus the analysis on upper tropospheric clouds. 


\subsection{Instrument Performance}

\subsubsection{BCP}

The total range of observed cloud number concentrations is shown in Figure 2. Assuming the sample area as reported by Beswick et al. ${ }^{32}$, and a typical mean aircraft cruising speed of $250 \mathrm{~ms}^{-1}$ we estimate the lower threshold for cloud particle detection with a temporal resolution of $4 \mathrm{~s}$ (IAGOS operation conditions) as $0.015 \mathrm{~cm}^{-3}$, but with a sampling uncertainty of $50 \%$ according to Poisson statistics. Beswick et al. ${ }^{33}$ used a threshold value of $0.050 \mathrm{~cm}^{-3}$ which corresponds to a count of 13 particles over $4 \mathrm{~s}$ sampling time and a sampling uncertainty of $25 \%$. On the other extreme, measurements in liquid water clouds ${ }^{32}$ demonstrate that the BCP works well up to cloud particle number concentrations as high as $200 \mathrm{~cm}^{-3}$. Those high cloud particle number concentrations, however, were never observed at IAGOS cruise conditions.

In our study, we categorise samples with $\mathrm{N}_{\text {ice }} \geq 0.015 \mathrm{~cm}^{-3}$ as "in-cloud" or cirrus, respectively, whereas samples with $N_{\text {ice }} \leq 0.001 \mathrm{~cm}^{-3}$ are recorded as zero-count events and considered cloud-free observations. Samples with $0.001 \mathrm{~cm}^{-3}<\mathrm{N}_{\text {ice }}<0.015 \mathrm{~cm}^{-3}$ are recorded as "indeterminate events", i.e. they cannot be unambiguously identified as clouds, but neither can they be identified as cloud-free. They most likely refer to very thin cirrus. In this $\mathrm{N}_{\text {ice }}$ regime, the digital resolution of the instrument becomes relevant and causes the noisy pattern for values smaller than the threshold of $0.015 \mathrm{~cm}^{-3}$.

The upper range of observed particle number concentrations $\left(N_{\text {ice }} \leq 50 \mathrm{~cm}^{-3}\right)$ is in accordance with the upper range of $\mathrm{N}_{\text {ice }}$ values reported from a large set of research aircraft observations ${ }^{11,12}$, whereas lower concentrations observed in these research flights reach $N_{\text {ice }}$ values as low as $10^{-4} \mathrm{~cm}^{-3}$. Hence, our data set is missing the very thin clouds with $10^{-4} \mathrm{~cm}^{-3} \leq N_{\text {ice }} \leq 0.015 \mathrm{~cm}^{-3}$ which stem mostly from cirrus with ice crystals larger than the BCP's upper detection limit of $75 \mu \mathrm{m}$ in diameter ${ }^{12}$. This observational constraint needs to be considered in the interpretation of the results.

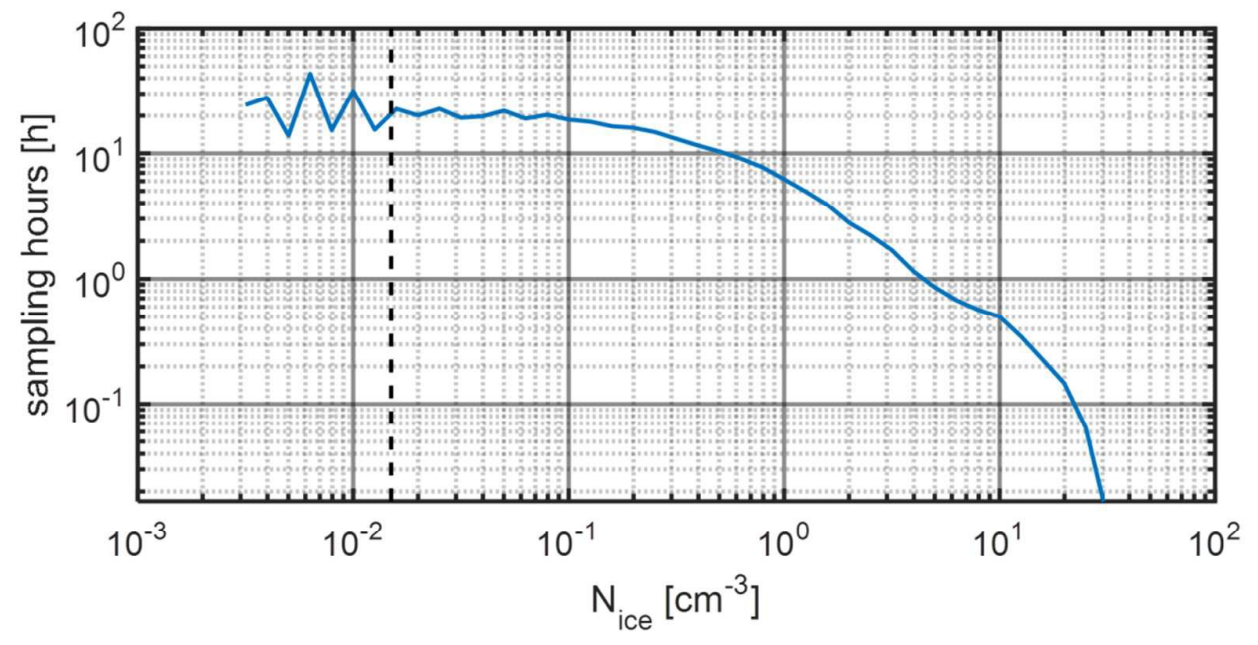

Figure 2. Total range of observed cloud particle number concentrations $N_{\text {ice; }}$ the threshold for cloud detection is set to $N_{\text {ice, } \min }=0.015 \mathrm{~cm}^{-3}$ (dashed line) with a sampling uncertainty of $50 \%$. 


\subsubsection{ICH}

The ICH data analysis procedure is described elsewhere ${ }^{22,35}$. Since sensors were partially operated over longer periods than originally planned, a shift of the sensor baseline was observed and required correction by the so-called "in-flight calibration method" (IFC) ${ }^{41}$. The IFC method corrects the potential drift of the sensor offset at zero relative humidity, which is the critical parameter in determining the uncertainty of the measurements. The sensor offset is determined from flight sequences in very dry conditions either in the stratosphere or in dry air masses descending over the subtropical oceans. Practically, all the raw voltage data is plotted as a function of $\mathrm{T}_{\text {sensor }}$ and the resulting lower voltage envelope is compared to the lower envelope of the $\mathrm{ICH}$ calibration data at $0 \%$ $\mathrm{RH}_{\text {liquid. }}$. The resulting gap is then identified as sensor offset and corrected. For details, see Figure 3 in Smit et al. $^{41}$. The IFC method was applied to the 2014/2015 data and checked against the MOZAIC data set from 2000 to $2009^{22}$. The comparison of the humidity data sets is shown in Figure 3 as probability distribution functions (PDF) of $\mathrm{RH}_{\text {ice }}$. The two years of IAGOS $\mathrm{RH}_{\text {ice }}$ data fit well into the range of the MOZAIC data set from 2000 to $2009^{22}$.

The response time of the $\mathrm{ICH}$ depends on the sensor temperature $\mathrm{T}_{\text {sensor }}$ which is approximately $35 \mathrm{~K}$ warmer than ambient air temperature $\mathrm{T}_{\mathrm{amb}}$ at cruise conditions ${ }^{36}$. For sensor temperatures between $245 \mathrm{~K}$ and $268 \mathrm{~K}\left(\mathrm{~T}_{\mathrm{amb}} \approx 210 \mathrm{~K}-233 \mathrm{~K}\right)$ the sensor response time is between $10 \mathrm{~s}$ and $100 \mathrm{~s}$, and exceeds $100 \mathrm{~s}$ for lower temperatures ${ }^{34}$. However, the $\mathrm{ICH}$ is capable of capturing faster changes in relative humidity but not to full amplitude. In that respect, peak values of $\mathrm{RH}_{\text {ice }}$ may be missed such that the reported $\mathrm{RH}_{\text {ice }}$ values should be considered lower boundary values.

One potential source of erroneously high RH observation by capacitive sensors operated inside a Rosemount inlet housing is the effect of partial or complete evaporation of hydrometeors due to adiabatic heating when entering the housing. This potential sensor cross-sensitivity to clouds was discussed in the literature ${ }^{35}$ but could be excluded for ice clouds by the intercomparison of data from $\mathrm{ICH}$ and research-grade hygrometers based on Ly- $\alpha$ photofragment fluorescence and an absolute tuneable diode laser absorption technique ${ }^{34}$. The intercomparison of $\mathrm{RH}$ data in cirrus did not indicate any $\mathrm{ICH}$ sensor cross-sensitivity to sampling in ice clouds so that our in-cloud $\mathrm{RH}_{\text {ice }}$ observations can be considered reliable.

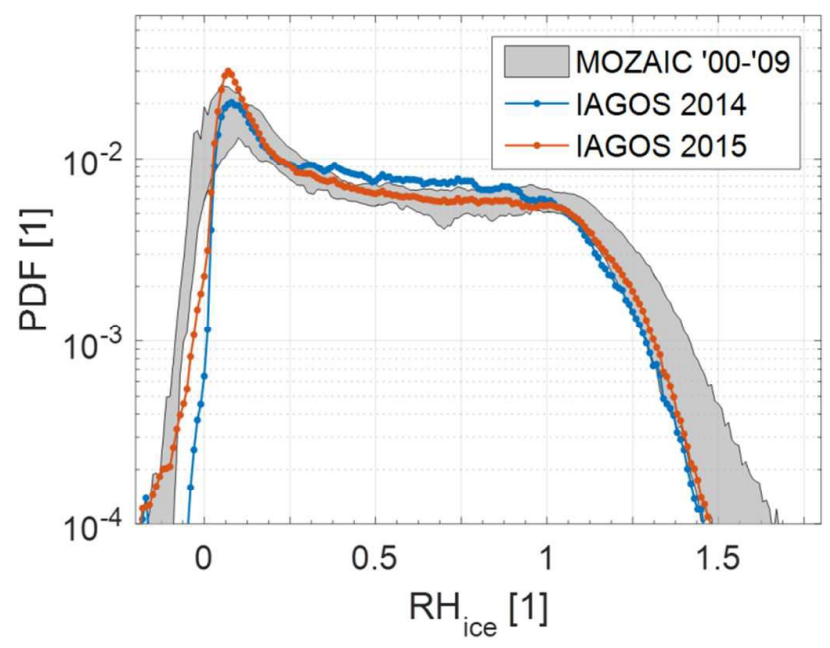

Figure 3. Probability density function of $\mathrm{RH}_{\text {ice }}$ for the IAGOS data sets collected in 2014 and 2015. The grey shaded area represents the value range covered by the MOZAIC data between 2000 and $2009^{22}$. 


\section{Results and Discussion}

Observations of $\mathrm{N}_{\text {ice }}$ and $\mathrm{RH}_{\text {ice }}$ are combined to investigate the distribution of $\mathrm{RH}_{\text {ice }}$ in clouds and to analyse cirrus cloud properties for northern hemispheric mid-latitude cirrus over the North Atlantic, North Pacific and the Eurasian Continent, and for subtropical to tropical cirrus over the tropical Atlantic and the Oceanian Continent close to the Pacific warm pool. Our observations are then discussed in comparison to results from recent airborne cirrus experiments, namely the field studies $\mathrm{ML}-\mathrm{CIRRUS}^{42}$ on mid-latitude cirrus over Europe and ACRIDICON-CHUVA ${ }^{43}$ on tropical cirrus over Amazonia. The interpretation of global scale in-situ observations with the assistance of processoriented field studies provides a broader picture of cirrus cloud properties in the global upper troposphere and extratropical tropopause.

\subsection{Global and Seasonal Data Coverage}

The IAGOS global set of $\mathrm{RH}_{\text {ice }}-\mathrm{N}_{\text {ice }}$ data obtained between July 2014 and October 2015 is shown in Figure 4 as PDF of observations, normalised to the complete data set of 6939 hours of sampling at $\mathrm{p}<350 \mathrm{hPa}$ in clear sky and inside clouds. The main flight routes of the IAGOS fleet are clearly visible. Starting from the entire data set, five regions were identified with sufficient data coverage for detailed analyses over the study period. Latitudinal bounds of mid-latitudes and sub-tropical to tropical latitudes are $30^{\circ} \mathrm{N}$ to $60^{\circ} \mathrm{N}$ and $30^{\circ} \mathrm{N}$ to $30^{\circ} \mathrm{S}$, similar to former studies ${ }^{17,33}$. Regional and seasonal distributions of sampling hours as well as fractional contributions of the indicated seasons and regions are listed in Table 1.

The data set splits into 2653 hours of observations at mid-latitudes and 4286 hours in the subtropics and tropics. From all observation we categorise 5.2\% (359 h) as cirrus with $\mathrm{N}_{\text {ice }} \geq 0.015 \mathrm{~cm}^{-3}, 2.9 \%$ $(199 \mathrm{~h})$ as indeterminate events and $91.9 \%$ (6377 h) as clear-sky observations. Although almost two thirds of the data originate from the subtropics and tropics regions, both data sets permit detailed analyses on a robust statistical basis. However, we refrain from investigating seasonal aspects for the study regions, since the seasons are not yet equally represented in the data sets; this topic will be subject of future work.

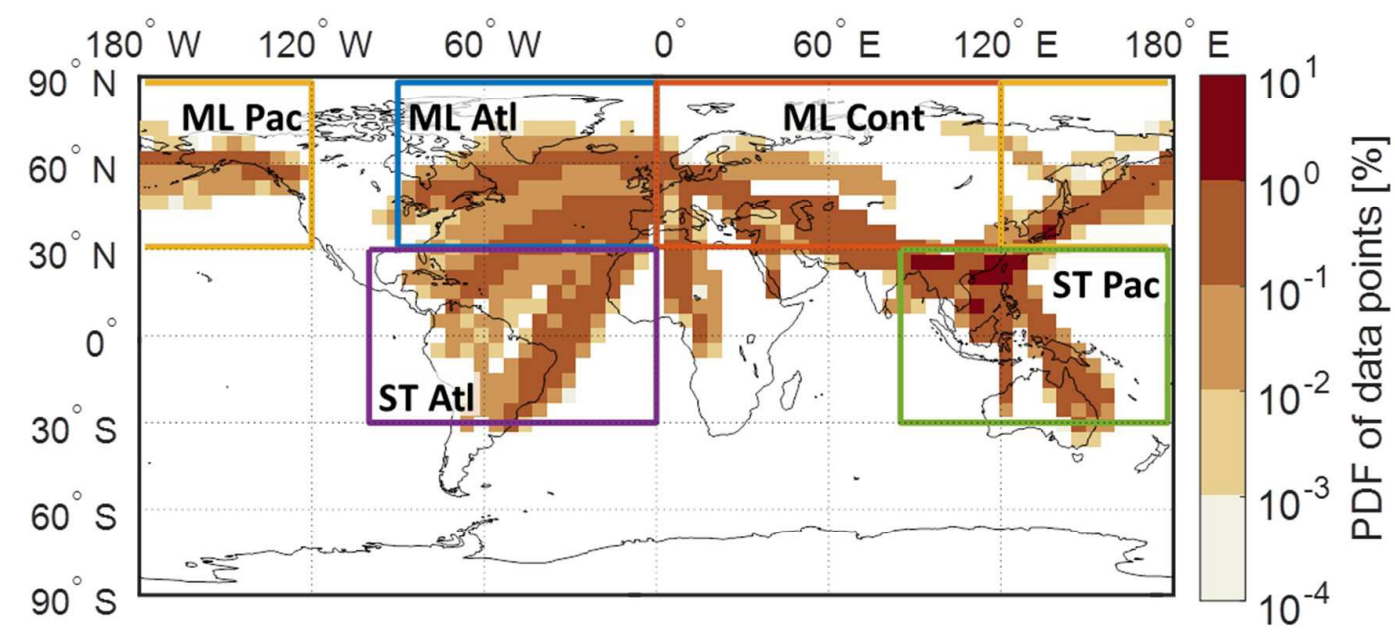

Figure 4. Data collected with ICH and BCP; the data set of 6939 hours of sampling is limited to the upper troposphere; boxes indicate regions with sufficient data coverage for detailed analyses. 
Table 1. Hours of sampling for regions and seasons, and respective fractions of seasons; data are normalised for regions.

\begin{tabular}{lllllll}
\hline Region & JA 2014 & SON 2014 & DJF 14/15 & MAM 2015 & JJA 2015 & SO 2015 \\
\hline Mid-Latitude all & 481 & 732 & 333 & 227 & 469 & 411 \\
& $18.1 \%$ & $27.6 \%$ & $12.6 \%$ & $8.5 \%$ & $17.7 \%$ & $15.5 \%$ \\
Subtropics all & 791 & 1679 & 811 & 331 & 357 & 317 \\
& $18.5 \%$ & $39.2 \%$ & $18.9 \%$ & $7.7 \%$ & $8.3 \%$ & $7.4 \%$ \\
\hline ML Continental & 71 & 214 & 118 & 156 & 270 & 260 \\
& $6.5 \%$ & $19.7 \%$ & $10.8 \%$ & $14.3 \%$ & $24.8 \%$ & $23.9 \%$ \\
ML Atlantic & 179 & 332 & 154 & 68 & 72 & 27 \\
& $21.5 \%$ & $39.9 \%$ & $18.6 \%$ & $8.1 \%$ & $8.7 \%$ & $3.2 \%$ \\
ML Pacific & 231 & 187 & 60 & 0 & 126 & 124 \\
& $31.8 \%$ & $25.6 \%$ & $8.2 \%$ & $0.0 \%$ & $17.3 \%$ & $17.1 \%$ \\
ST Atlantic & 0 & 297 & 439 & 114 & 41 & 13 \\
& $0.0 \%$ & $32.8 \%$ & $48.5 \%$ & $12.7 \%$ & $4.5 \%$ & $1.5 \%$ \\
ST Pacific & 682 & 1133 & 321 & 0 & 171 & 176 \\
& $27.5 \%$ & $45.6 \%$ & $12.9 \%$ & $0.0 \%$ & $6.9 \%$ & $7.1 \%$ \\
\hline
\end{tabular}

\subsection{Global Scale Distribution of Cirrus Observations}

The annually averaged global distribution of cirrus cloud observations by IAGOS aircraft is presented in Figure 5. The global patterns correspond to features reported from annually averaged cirrus cloud coverage data from CloudSat and CALIPSO satellites ${ }^{14}$. Relating the vertical distribution of cirrus cloud occurrence from CloudSat/CALIPSO observations to the aircraft cruise altitude band between $8 \mathrm{~km}$ and $13 \mathrm{~km}$ we find that our observations cover all cirrus occurrences at mid-latitudes, while we stay mostly below the hot spot of cirrus occurrence over the tropics between 12 and $18 \mathrm{~km}$. Nevertheless, the cirrus hotspots over the subtropical and tropical regions are both reported from space-borne observations and from IAGOS in-situ observations.

At mid-latitudes, where altitude bands of cirrus observations from satellites and from in-situ observations by passenger aircraft coincide, the regional distribution patterns of enlarged cirrus occurrence over the North Atlantic between Europe and Central America and over the Northern Pacific are found in both data sets. For a detailed intercomparison, see Figure 5 and Figure 1 in Sassen et al. ${ }^{14}$ at http://onlinelibrary.wiley.com/doi/10.1029/2008JD009972/full. Similar global distributions of IAGOS cloud observations are reported in a previous study focusing on BCP measurements only ${ }^{33}$.

The cumulative distribution functions of ice crystal number densities $\mathrm{N}_{\text {ice }}$ for the five regions of interest are presented in Figure 6, and fractions of cloud observations below the indicated threshold values $\mathrm{N}_{\text {thresh }}$ are detailed in Table 2 . It has to be noted that by applying the cloud threshold value of $\mathrm{N}_{\text {ice, } \min }=0.015 \mathrm{~cm}^{-3}$, between $40 \%$ (subtropical Pacific) and $61 \%$ (mid-latitude continental) of the observations fall into the category of "indeterminate events", i.e. very thin cirrus. For evaluating the fraction of observations of thin to very thin ice clouds including "indeterminate events", we calculated the number of observations with $\mathrm{N}_{\text {ice }} \leq 0.1 \mathrm{~cm}^{-3}$, which is the most probable $\mathrm{N}_{\text {ice }}$ value reported from research aircraft measurements with advanced instrumentation ${ }^{12,27}$. 


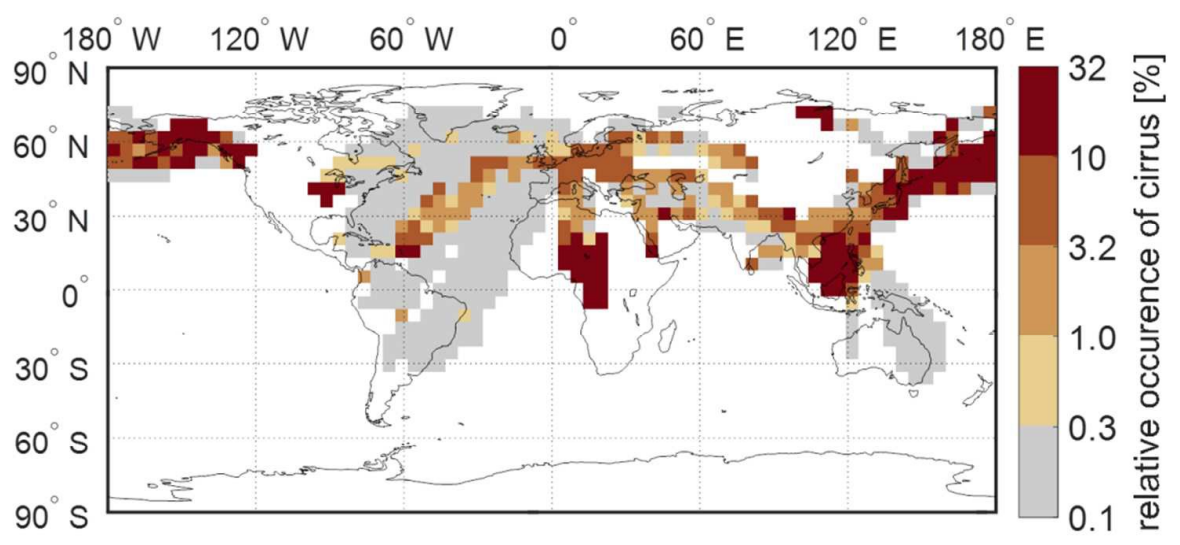

Figure 5. Annual mean of global scale cirrus cloud coverage as observed by IAGOS-CORE aircraft.

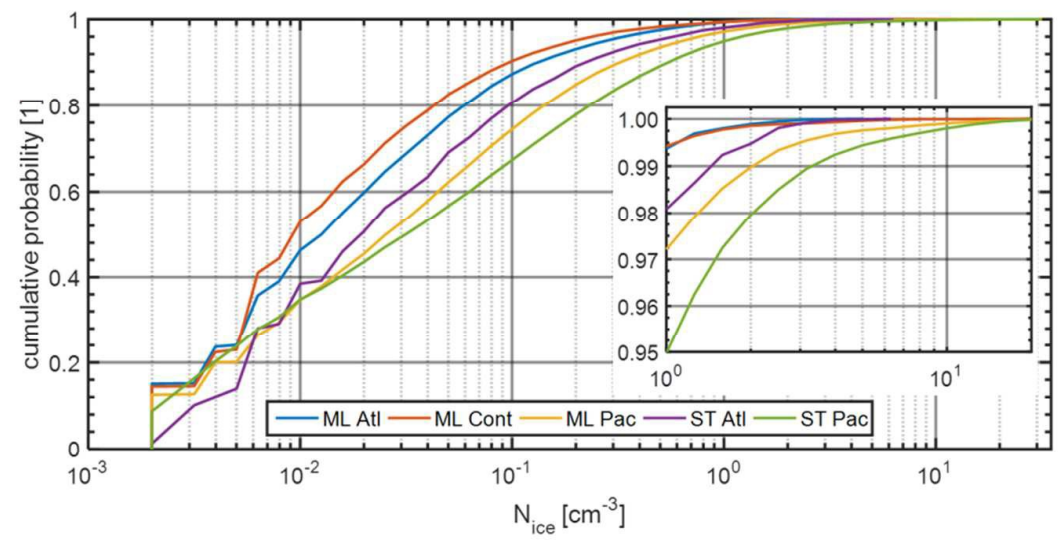

Figure 6. Cumulative probability distribution for cloud particle number concentrations $\mathrm{N}_{\text {ice }}$, specified for the indicated regions.

Table 2. Fraction of cloud observations with $\mathrm{N}_{\text {ice }}$ below the threshold value $\mathrm{N}_{\text {thresh }}$.

\begin{tabular}{lccc}
\hline Region & $\mathrm{N}_{\text {thresh }}=0.015 \mathrm{~cm}^{-3}$ & $\mathrm{~N}_{\text {thresh }}=0.10 \mathrm{~cm}^{-3}$ & $\mathrm{~N}_{\text {thresh }}=1.0 \mathrm{~cm}^{-3}$ \\
\hline ML Continental & $61 \%$ & $90 \%$ & $99.4 \%$ \\
ML Atlantic & $54 \%$ & $87 \%$ & $99.4 \%$ \\
ST Atlantic & $44 \%$ & $81 \%$ & $98.0 \%$ \\
ML Pacific & $41 \%$ & $74 \%$ & $97.0 \%$ \\
ST Pacific & $40 \%$ & $67 \%$ & $95.0 \%$ \\
\hline
\end{tabular}

Keeping in mind the limitations of the BCP when sensing ice crystal number densities below $10^{-3} \mathrm{~cm}^{-3}$ and for not detecting ice crystals larger than approximately $75 \mu \mathrm{m}$ in diameter, the herein reported fractions of thin to very thin clouds still have to be considered lower limits. On the other hand, dense clouds with $\mathrm{N}_{\text {ice }}>1.0 \mathrm{~cm}^{-3}$ contribute between less than $1 \%$ over mid-latitude continental regions and $5 \%$ over the subtropical and tropical Pacific Ocean. Rare events of extremely dense clouds with $\mathrm{N}_{\text {ice }}>$ $10 \mathrm{~cm}^{-3}$ contribute less than $0.1 \%$ and are found exclusively in the subtropics and tropics. 


\subsection{Vertical Distribution of Cirrus Properties}

The vertical distribution of cloud observations is shown as the correlation between pressure and incloud temperature in Figure $7 a, b$ and between pressure and $N_{\text {ice }}$ in Figure $7 c$, d. Finally, $N_{\text {ice }}$ vs. temperature is added in Figure 7e, f. Here, we limit the analysis to mid-latitude, subtropics and tropics observations and neglect further separation into the five regions defined above for the sake of statistical robustness. It should be noted that for standard atmosphere conditions the pressure range from $350 \mathrm{hPa}$ to $170 \mathrm{hPa}$ corresponds to an altitude range from $8.1 \mathrm{~km}$ to $12.8 \mathrm{~km}$.

As is shown in Figure 7a, b, the coldest cloud observations are associated with pressures below 200 $\mathrm{hPa}$ and altitudes above $12 \mathrm{~km}$, respectively, while warmer in-cloud temperatures are predominantly linked to higher pressures. The clear structure of the atmosphere in the subtropics and tropics as seen in Figure $7 \mathrm{~b}$ can be explained by the fact that the cloud observations at cruise altitude below $13 \mathrm{~km}$ occur in upper tropospheric air masses well separated from the TTL at approx. $16-18 \mathrm{~km}$ with its specific dynamic processes.

Thus, the correlation between in-cloud temperature and pressure is determined by the moist adiabatic lapse rate driven by uplifting in deep convective clouds ${ }^{15}$. Cirrus clouds at mid-latitudes are observed in the uppermost troposphere where tropopause dynamics as well as mixing processes and vertical displacement driven by synoptic weather systems play a role. This difference in the dynamical conditions is manifested in the scattered correlation between in-cloud temperature and pressure shown in Figure 7a.

The vertical distribution of $\mathrm{N}_{\text {ice }}$ is depicted in Figure $7 \mathrm{c}, \mathrm{d}$ with respective relations between $\mathrm{N}_{\text {ice }}$ and in-cloud temperature in Figure $7 \mathrm{e}, \mathrm{f}$. The range of observed cloud number densities varies only weakly with decreasing pressure, with a tendency towards higher median $\mathrm{N}_{\text {ice }}$ values at higher pressures and thus higher temperatures. The range of $\mathrm{N}_{\text {ice, }}$, however, increases significantly with altitude with higher maximum $\mathrm{N}_{\text {ice }}$ values at higher altitudes. Part of the more frequent occurrence of $\mathrm{N}_{\text {ice }}>1.0 \mathrm{~cm}^{-3}$ at altitudes above $10.4 \mathrm{~km}(\mathrm{p} \leq 250 \mathrm{hPa}$ ) at mid-latitudes might be attributed to the occasional sampling of contrails. Similar observations are reported from ML-CIRRUS ${ }^{11,12}$; details are discussed in Section 3.6. The densest clouds with $\mathrm{N}_{\text {ice }}>10 \mathrm{~cm}^{-3}$ are found over the subtropics and tropics at temperatures above $225 \mathrm{~K}$.

The observed range of $\mathrm{N}_{\text {ice }}$ values can be interpreted in terms of two types of cirrus clouds with differing formation mechanisms and microphysical properties: in-situ origin cirrus where the ice crystals form directly from the gas phase via different ice nucleation mechanisms (heterogeneous, homogeneous), and liquid origin cirrus where ice crystals form by freezing of liquid cloud drops (heterogeneous, homogeneous) during uplift to the cirrus temperature range ${ }^{11,12}$.

The key features that distinguish liquid origin cirrus from in-situ origin cirrus are higher frequencies of high ice water content ( $>100$ ppmv; property not measured in IAGOS), higher $\mathrm{N}_{\text {ice }}$ values, and larger ice crystals. From extensive observations by research aircraft, a median value of about $0.1 \mathrm{~cm}^{-3}$ is reported for in-situ origin cirrus, independent of altitude but with higher variability above $9 \mathrm{~km}$ altitude, whereas median $\mathrm{N}_{\text {ice }}$ values slightly but notably higher than $0.1 \mathrm{~cm}^{-3}$ are found for liquid origin clouds ${ }^{12}$. 

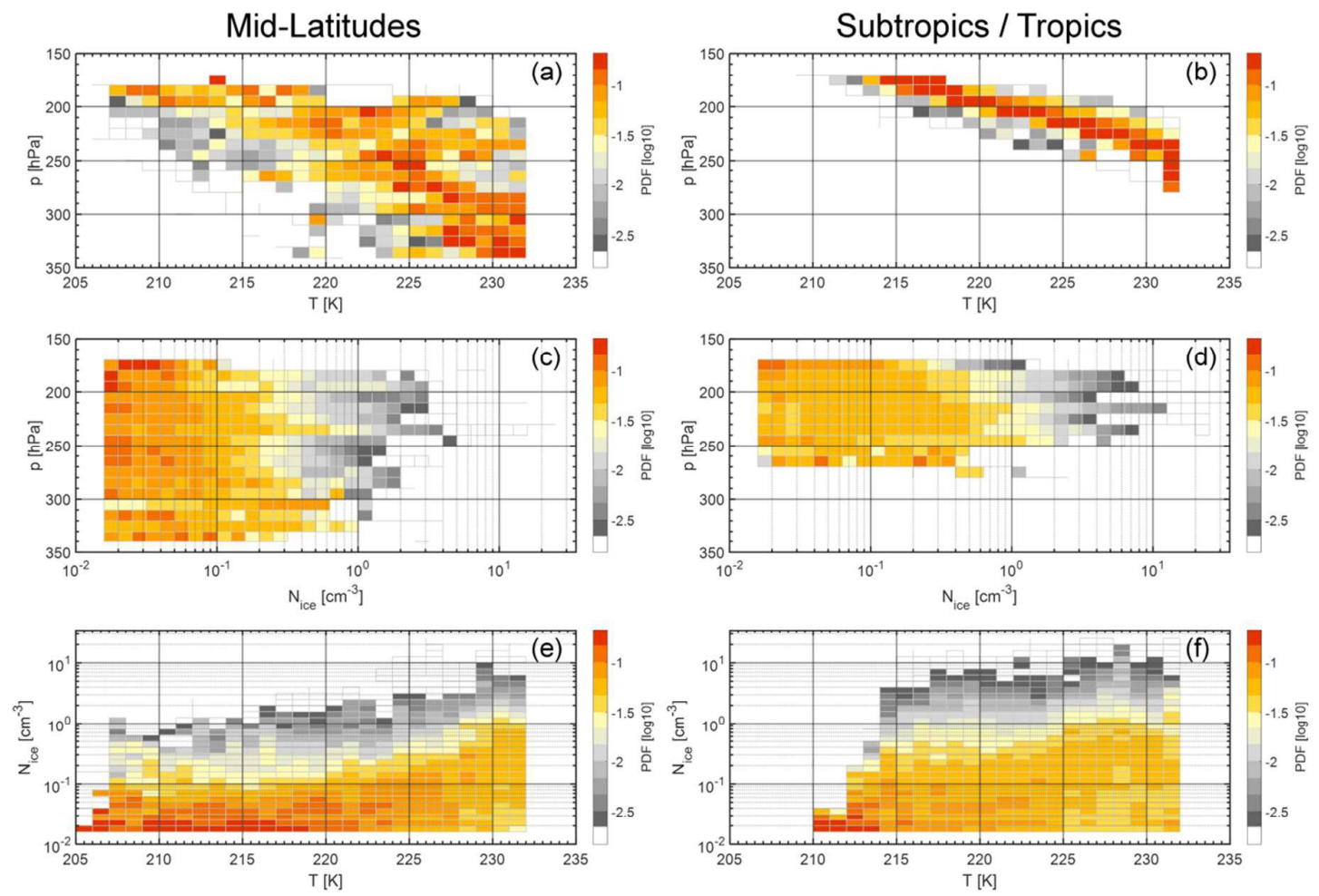

Figure 7. Top row: Vertical distribution of in-cloud temperatures $T$ for mid-latitudes (a) and subtropics to tropics (b); middle row: same for $N_{i c e}$ as a function of pressure for mid-latitudes (c) and subtropics to tropics (d); bottom row: $N_{\text {ice }}$ vs. in-cloud temperature $T$. In the subtropics (d) data exist for $p>270 \mathrm{hPa}$, but were excluded because of $T>233 \mathrm{~K}$.

Applying this scheme to our observations, we propose that the majority of cirrus clouds at midlatitudes are of in-situ origin with notable contributions of liquid origin clouds at altitudes below $9.6 \mathrm{~km}$ (approx. $280 \mathrm{hPa}$ ) where we find higher $\mathrm{N}_{\text {ice }}$ values more frequently than in the overlying air masses. This proposed vertical distribution of cirrus types is supported by results from a trajectorybased classification of ERA-Interim ice clouds over the North Atlantic ${ }^{13}$. According to this study, insitu origin cirrus and liquid origin cirrus, respectively, contribute approx. two thirds and one third to the total cirrus occurrence at $300 \mathrm{hPa}$, whereas at $200 \mathrm{hPa}$ all cirrus clouds are of in-situ origin.

Over the subtropics and tropics, the contribution of deep convective systems to cirrus clouds is considered significantly larger than at mid-latitudes. CloudSat/CALIPSO analyses show that at low latitudes and under certain conditions deep convective clouds (liquid origin) and cirrus clouds (in-situ origin) may occur at the same frequency ${ }^{15}$. In accordance, we observe significantly higher $\mathrm{N}_{\text {ice }}$ values over the tropics and subtropics compared to mid-latitudes. Particularly, the events of dense clouds with $\mathrm{N}_{\text {ice }}>1.0 \mathrm{~cm}^{-3}$ may be explained by the formation of liquid origin cirrus in deep convection.

\subsection{Distribution of $\mathrm{RH}_{\text {ice }}$ in Cirrus and in Clear Sky}

To further understand cirrus origin, we investigated the distribution of $\mathrm{RH}_{\text {ice }}$ in clouds and in clear sky. The resulting probability distribution functions of $\mathrm{RH}_{\text {ice }}$ are shown in Figure 8, further divided into the five different regions. As shown in Figure $8 \mathrm{a}$, we find the most probable values of $\mathrm{RH}_{\text {ice }}$ in cirrus at icesupersaturations of $105-110 \%$ for all studied regions. Although, we have to recall the measurement 
uncertainty of the $\mathrm{ICH}$ of $5 \% \mathrm{RH}$, the observations indicate a preference for slight ice-supersaturation in cirrus. Remarkably, there is no significant difference in the in-cloud $\mathrm{RH}_{\text {ice }}$ distributions between the studied regions. In clear sky, we found $85 \%$ to $95 \%$ of all observations below ice-supersaturation which is in agreement with other studies on the distribution of relative humidity in the upper troposphere and tropopause region ${ }^{24,44}$. Again, the $\mathrm{RH}_{\text {ice }}$ distributions in clear sky show no significant dependence on the region of observation. All distributions show the exponential decay in the supersaturated regime, as reported from many observations ${ }^{17,18,20}$.

The observed preference for ice-supersaturation in cirrus, however, conflicts the common understanding that in cirrus at thermodynamic equilibrium the $\mathrm{PDF}$ of $\mathrm{RH}_{\text {ice }}$ centres at $100 \%$. Several field studies report this modal value of $\mathrm{RH}_{\text {ice }}=100 \%{ }^{24,25,27}$ while other studies found slight supersaturations with $\mathrm{RH}_{\text {ice }} \approx 100 \%-110 \%{ }^{26}$, similar to our observations.

Theoretical investigations of cirrus in dynamic equilibrium argue that in clouds with continuous uplifting the dynamic equilibrium $\mathrm{RH}_{\text {ice }}$ tends to supersaturation over the complete temperature range $^{27}$, with higher dynamic equilibrium supersaturations and higher $N_{i c e}$ values for higher updraft velocities. The reason is that ice clouds are open thermodynamic systems. A persistent upward motion acts as an external forcing that constitutes a source of supersaturation causing the cloud to relax to a higher dynamic equilibrium. This behaviour is also found from model simulations ${ }^{45,46}$ showing that ice clouds can stay at slight supersaturations of $\mathrm{RH}_{\text {ice }} \approx 105-110 \%$.

Given the range of observed vertical updraft velocities in cirrus, the span of measured modal $\mathrm{RH}_{\text {ice }}$ values can be explained by this mechanism. Note that higher $\mathrm{RH}_{\text {ice }}$ can be attained before the dynamic equilibrium is reached, when the lowering of the water vapour saturation value $\left(e_{\text {sat, ice }}(T)\right)$ by cooling of the air due to strong updrafts is faster than the depletion of the ambient gas phase water vapour (e) by ice crystal growth (commemorate $\mathrm{RH}_{\text {ice }}=e / e_{\text {sat, ice }}(\mathrm{T}) \times 100$ ).
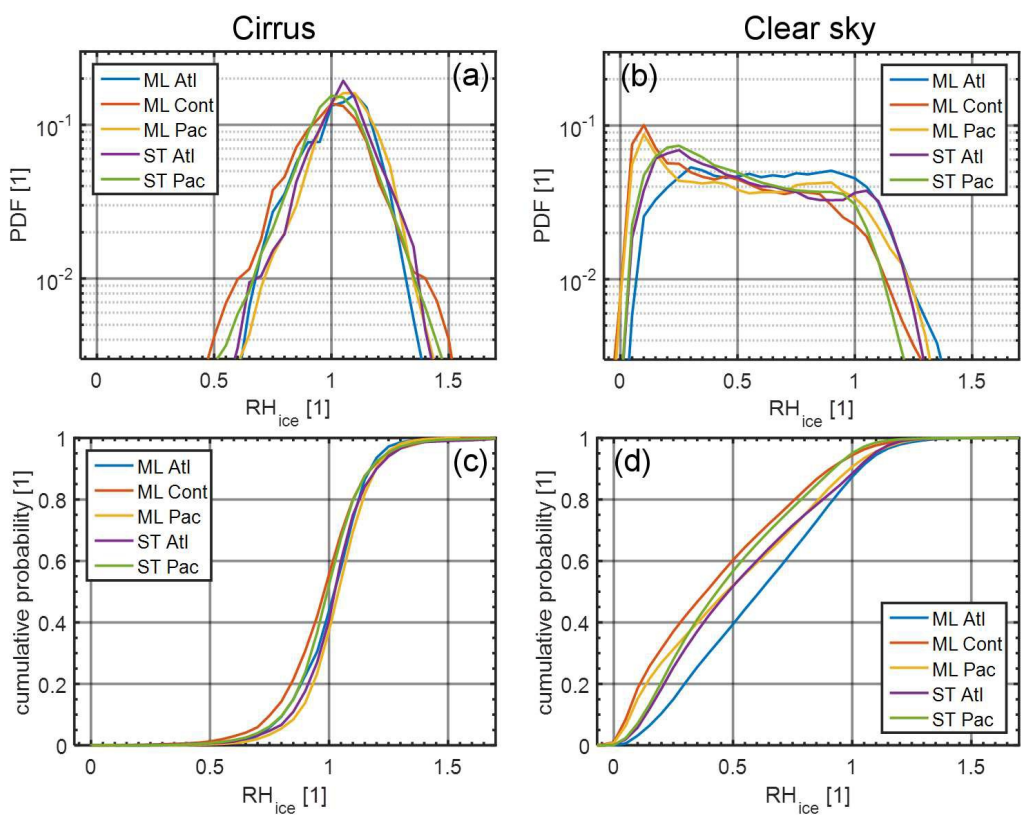

Figure 8. Probability distribution functions of $\mathrm{RH}_{\text {ice }}(a, b)$ and cumulative probability distribution of $\mathrm{RH}_{\text {ice }}(c, d)$ for the identified regions in cirrus and in clear sky. 


\subsection{Correlation of $\mathrm{RH}_{\text {ice }}$ and $\mathrm{N}_{\text {ice }}$}

We finally explored $\mathrm{RH}_{\text {ice }}-\mathrm{N}_{\text {ice }}$ data set for the expected relationship between higher dynamic equilibrium supersaturations at higher updraft velocities and the resulting higher $\mathrm{N}_{\text {ice }}$ values. The distributions of $\mathrm{RH}_{\text {ice }}$ in cirrus as a function of $\mathrm{N}_{\text {ice }}$ are plotted in Figure 9 for mid-latitude and subtropical/tropical cirrus. The most evident feature of our analysis is the strong connection between the number concentration of ice crystals $\mathrm{N}_{\text {ice }}$ and the respective distribution of $\mathrm{RH}_{\text {ice }}$ in cirrus. In both data sets high $\mathrm{N}_{\text {ice }}$ values are associated with high $\mathrm{RH}_{\text {ice }}$ values well above $120 \%$, particularly in the tropics. The pattern is less pronounced over the North Atlantic and additionally possibly contaminated by contrails. Values of $\mathrm{N}_{\text {ice }} \geq 1 \mathrm{~cm}^{-3}$ are found more frequently in the tropics and subtropics, compared to mid-latitudes.

Recalling that we did not find significant differences in the in-cloud $\mathrm{RH}_{\text {ice }}$ distributions between the studied regions (see Figure 8), we analysed the probability distribution functions of $\mathrm{RH}_{\text {ice }}$ in clouds for the different regimes of cloud particle number concentrations of $N_{\text {ice }} \leq 0.1 \mathrm{~cm}^{-3}, N_{\text {ice }}$ between $0.1 \mathrm{~cm}^{-3}$ and $1.0 \mathrm{~cm}^{-3}$, and $\mathrm{N}_{\text {ice }}>1.0 \mathrm{~cm}^{-3}$. The obtained distribution functions of $\mathrm{RH}_{\text {ice }}$ are shown in Figure 10 and respective percentiles of the $\mathrm{RH}_{\text {ice }}$ distributions in Table 3.

For cirrus with $\mathrm{N}_{\text {ice }} \leq 0.1 \mathrm{~cm}^{-3}$, the gas-phase is saturated with respect to ice and $\mathrm{RH}_{\text {ice }}$ is centred at $100 \%$. For cirrus with $\mathrm{N}_{\text {ice }}$ between $0.1 \mathrm{~cm}^{-3}$ and $1.0 \mathrm{~cm}^{-3}$ the gas phase is slightly ice-supersaturated and $\mathrm{RH}_{\text {ice }}$ is centred at $105-110 \%$. Finally, cirrus with $\mathrm{N}_{\text {ice }}>1.0 \mathrm{~cm}^{-3}$ show high ice-supersaturation and $\mathrm{RH}_{\text {ice }}$ reaches values as large as $150 \%$ which is about the homogeneous freezing threshold in the sampled temperature range and can be reached in regions of high updrafts ${ }^{11}$. Higher $\mathrm{RH}_{\text {ice }}$ values above $160 \%$ close to water saturation are observed exclusively in the subtropics and tropics. They are most likely associated to deep convective systems in which supercooled liquid droplets may contaminate the $\mathrm{ICH}$ sensor.

As discussed in Section 3.4, the dynamic equilibrium $\mathrm{RH}_{\text {ice }}$ in cirrus with continuous uplifting tends to supersaturation, and higher dynamic equilibrium supersaturations are associated with higher updraft velocities. With that said, we may infer information on the impact of updraft and downdraft processes for the different $\mathrm{N}_{\text {ice }}$ regimes. It is noticeable that the distribution functions of $\mathrm{RH}_{\text {ice }}$ notably for $\mathrm{N}_{\text {ice }}>1.0 \mathrm{~cm}^{-3}$ differ significantly between mid-latitudes and the subtropics and tropics. While dense ice clouds at mid-latitudes show clear regions of updrafts $\left(\mathrm{RH}_{\text {ice }}>100 \%\right)$ as well as downdrafts $\left(\mathrm{RH}_{\text {ice }}<100 \%\right)$, the same type of cirrus in the tropics and subtropics is dominated by strong updrafts, which may explain the observation of high $\mathrm{N}_{\text {ice }}$ values. This relationship between $\mathrm{RH}_{\text {ice }}$ and $\mathrm{N}_{\text {ice }}$ has not been observed so far, mainly because this kind of study requires a data set of sufficient size to ensure statistical robustness of the obtained results.

Table 3. Percentiles of the $\mathrm{RH}_{\text {ice }}$ distributions for the different regimes of cloud density

\begin{tabular}{lrrrrrrrr}
\hline & \multicolumn{4}{c}{ Mid-Latitudes } & \multicolumn{3}{c}{ Subtropics / Tropics } \\
\cline { 2 - 9 } $\mathrm{N}_{\text {ice }}$ & $\begin{array}{r}\text { No. of } \\
\text { data }\end{array}$ & $\begin{array}{r}45 \text { perc. } \\
{\left[\% \mathrm{RH}_{\text {ice}}\right]}\end{array}$ & $\begin{array}{r}\text { Median } \\
{\left[\% \mathrm{RH}_{\text {ice }}\right]}\end{array}$ & $\begin{array}{r}55 \text { perc. } \\
{\left[\% \mathrm{RH}_{\text {ice }}\right]}\end{array}$ & $\begin{array}{r}\text { No. of } \\
\text { data }\end{array}$ & $\begin{array}{r}45 \text { perc. } \\
{\left[\% \mathrm{RH}_{\text {ice }}\right]}\end{array}$ & $\begin{array}{r}\text { Median } \\
{\left[\% \mathrm{RH}_{\text {ice}}\right]}\end{array}$ & $\begin{array}{r}55 \text { perc. } \\
{\left[\% \mathrm{RH}_{\text {ice}}\right]}\end{array}$ \\
\hline$<0.1$ & 65616 & 102.4 & 104.1 & 105.9 & 83812 & 96.6 & 98.3 & 100.1 \\
$0.1-1.0$ & 33529 & 104.9 & 106.3 & 107.8 & 83721 & 100.2 & 101.8 & 103.4 \\
$>1.0$ & 3555 & 106.0 & 107.5 & 109.0 & 17175 & 104.6 & 106.3 & 1.07 .9 \\
\hline
\end{tabular}




\section{Faraday Discussions}

FD-ART-01-2017-000006
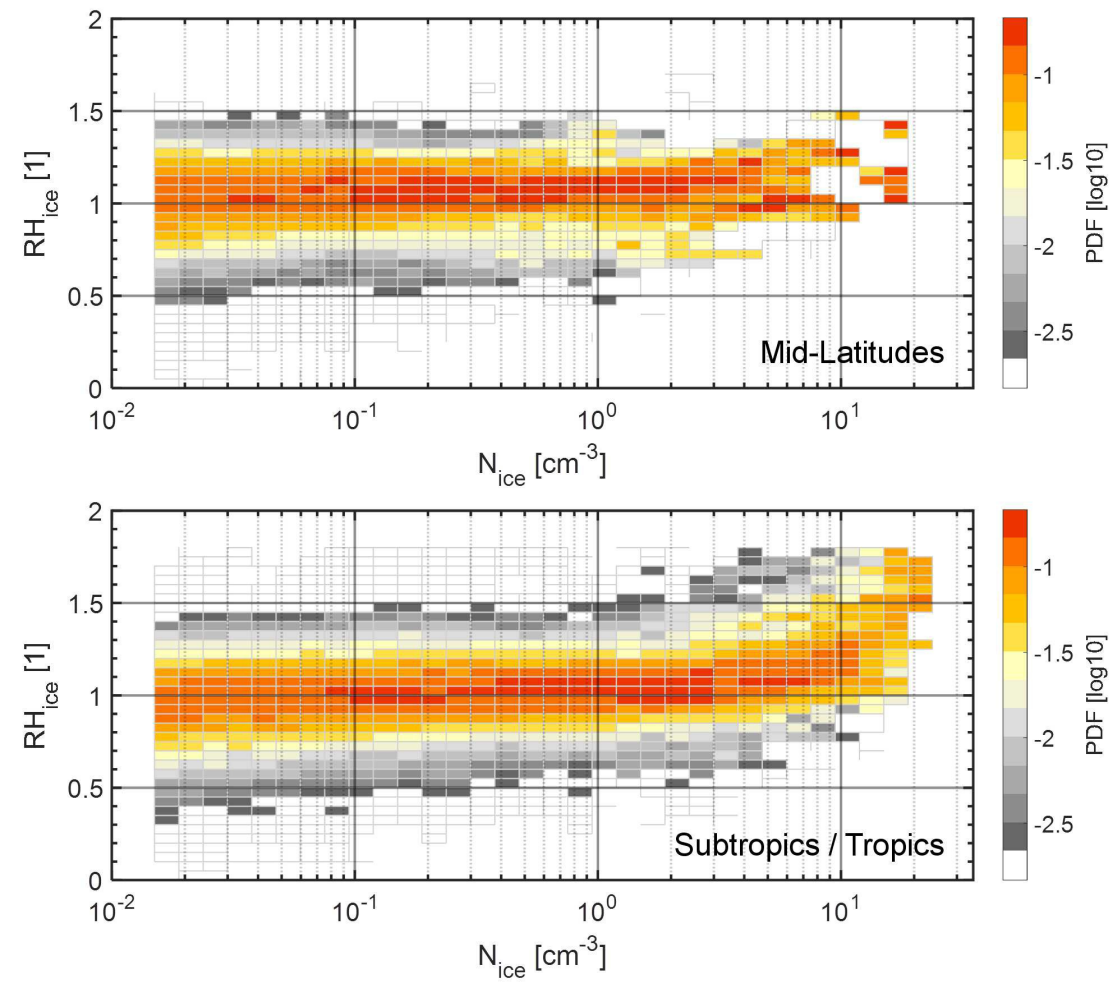

Figure 9. $R H_{\text {ice }}$ vs. $N_{\text {ice }}$ for mid-latitude cirrus and for subtropical and tropical cirrus.
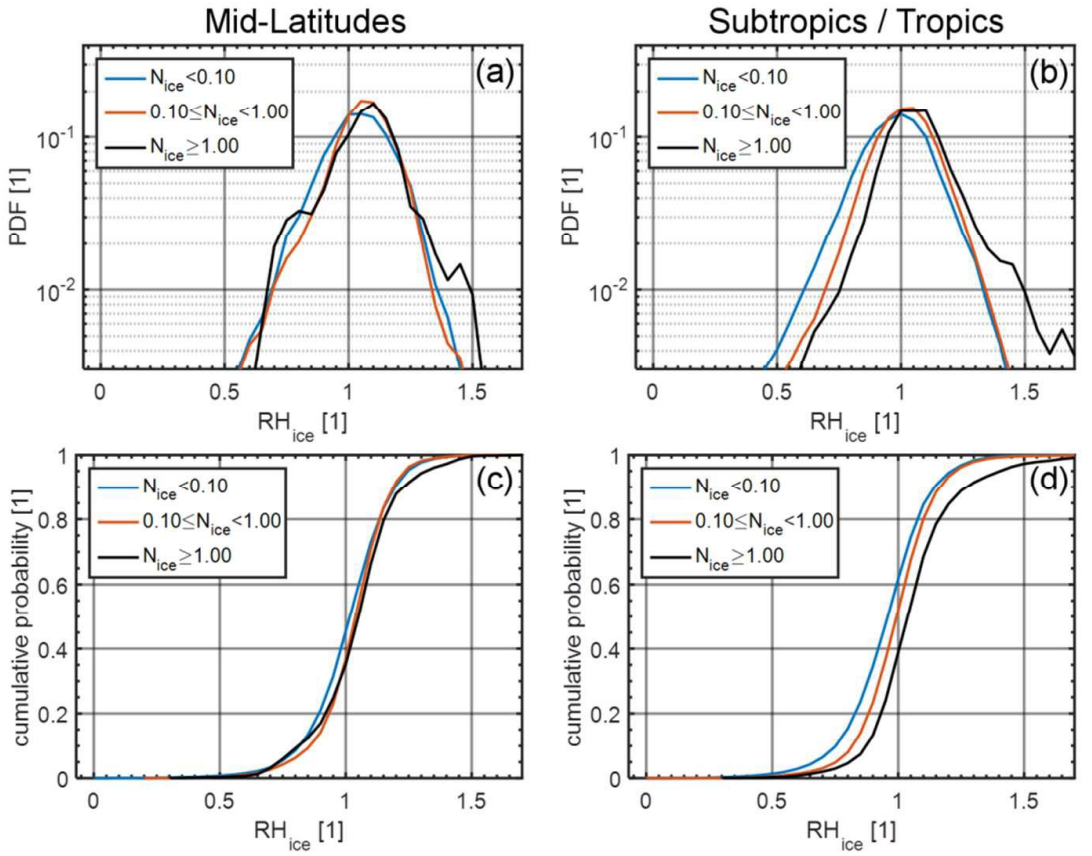

Figure 10. Probability distribution function of $\mathrm{RH}_{\text {ice }}$ for the different $\mathrm{N}_{\text {ice }}$ regimes (unit is $\mathrm{cm}^{-3}$ ) at midlatitudes (a) and subtropics to tropics (b); same for the cumulative distribution functions in (c) and (d). 


\subsection{Contrails}

Aviation-induced cirrus or persistent contrails, respectively, form preferably at temperatures below $225 \mathrm{~K}$. These clouds are characterised typically by $\mathrm{N}_{\text {ice }} \geq 1 \mathrm{~cm}^{-3}$ which is larger than up to two orders of magnitude compared to the average of natural cirrus clouds ${ }^{47}, \mathrm{RH}_{\text {ice }} \leq 120 \%$ and small ice crystal size, with a considerable fraction of observations in air sub-saturated with respect to ice ${ }^{48}$. We analysed the subset of data collected in the North Atlantic Flight Corridor $\left(40^{\circ} \mathrm{N}-60^{\circ} \mathrm{N}, 65^{\circ} \mathrm{W}-5\right.$ ${ }^{\circ} \mathrm{W}$ ) as the region of densest air traffic worldwide for signatures of contrails. The $\mathrm{RH}_{\text {ice }}$ distribution for thinner cirrus $\left(\mathrm{N}_{\text {ice }}<0.1 \mathrm{~cm}^{-3}\right)$ in Figure 11 shows strong similarities to average mid-latitude cirrus (Figure 10), whereas for dense

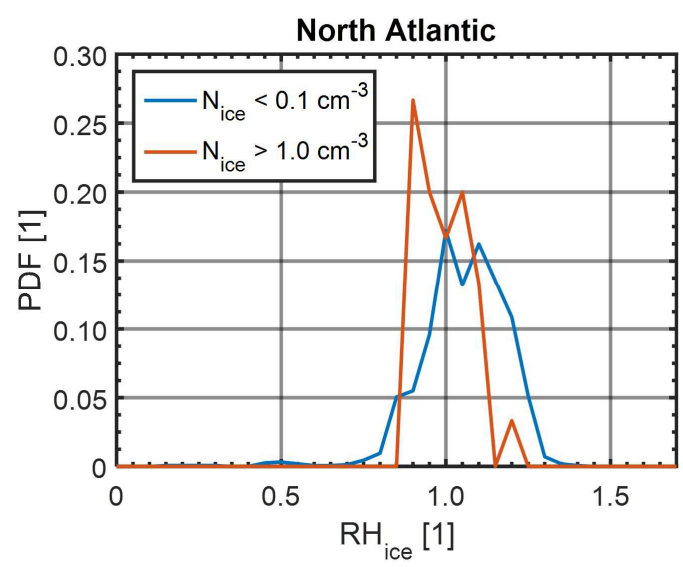

Figure 11. Probability distribution function of $\mathrm{RH}_{\text {ice }}$ over the North Atlantic Flight Corridor for thin ( $N_{\text {ice }}$ $\left.<0.1 \mathrm{~cm}^{-3}\right)$ and dense $\left(N_{\text {ice }}>1.0 \mathrm{~cm}^{-3}\right)$ cirrus.

clouds $\left(\mathrm{N}_{\text {ice }}>1.0 \mathrm{~cm}^{-3}\right.$ ), a remarkable congruence to $\mathrm{RH}_{\text {ice }}$ observations inside individual contrails ${ }^{48}$ is found. The observed distribution shows signatures of dissolving $\left(\mathrm{RH}_{\text {ice }}<100 \%\right)$ and persistent $\left(\mathrm{RH}_{\text {ice }}>\right.$ $100 \%)$ contrails. Aviation-induced cirrus likely dominates the fraction of dense clouds over this region, but contributes less than $0.5 \%$ to all clouds. For thinner clouds, however, we cannot distinguish aviation-induced from natural cirrus, since properties are similar. Furthermore, aviationinduced cirrus should not be treated separately, since they are part of the global cloudiness in the Anthropocene.

\subsection{Comparison to Research Aircraft Studies}

Since the strong connection between the number concentration of ice crystals $\mathrm{N}_{\text {ice }}$ and the respective distribution of $\mathrm{RH}_{\text {ice }}$ in cirrus has not been reported before, we want to ensure that our findings are not caused by specific flight routes of passenger aircraft. Hence, we discuss our observations in comparison to results from recent dedicated airborne cirrus experiments $\mathrm{ML}-\mathrm{CIRRUS}^{42}$ on midlatitude cirrus over Europe and ACRIDICON-CHUVA ${ }^{43}$ on tropical cirrus over Amazonia.

The scientific payload of these studies included the highly sophisticated instruments NIXE-CAPS ${ }^{12}$ for measuring ice crystals and $\mathrm{HAI}^{49}$ or $\mathrm{SHARC}^{50}$ for measuring atmospheric water vapour. Both research campaigns were focused on the process understanding of cirrus cloud formation and evolution but for very different environments. Details of the field campaigns and the deployed instrumentation can be found in the respective overview publications ${ }^{42,43}$ and research publications ${ }^{11,12}$.

The correlations of $\mathrm{N}_{\text {ice }}$ to mass mean radius $\mathrm{R}_{\text {ice }}$ of the ice crystal size distribution are shown in Figure 12 , colour-coded for in-cloud $\mathrm{RH}_{\text {ice. }}$. We compare these correlations to our observations of $\mathrm{RH}_{\text {ice }}-\mathrm{N}_{\text {ice }}$ 

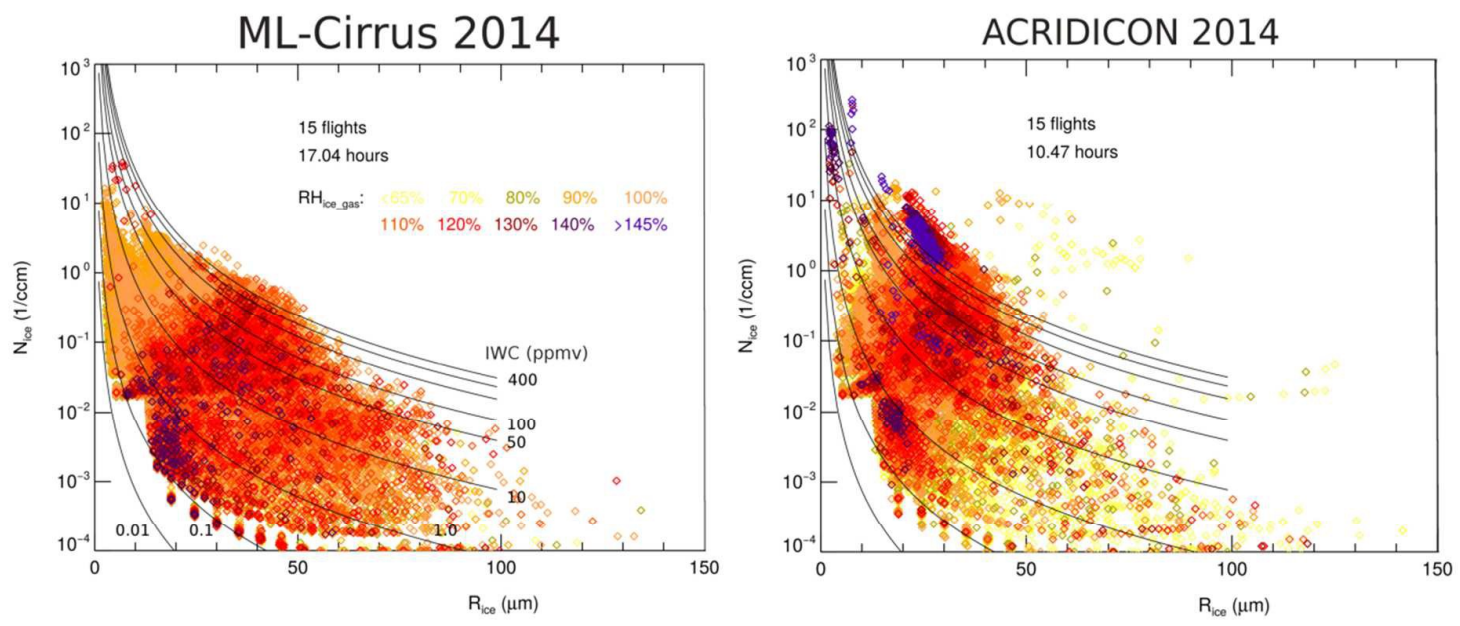

Figure 12. Scatter plots of $N_{\text {ice }}$ as a function of mass mean radius $R_{\text {ice }}$ for research aircraft-based observations at mid-latitudes during ML-CIRRUS and in the subtropics to tropics during ACRIDICONCHUVA experiments; the colour code represents $R H_{\text {ice }}$ for each observation, ice crystals were measured by two sophisticated optical instruments ${ }^{12}$ capable of detecting a large size range 0.6 950 um diameter) as well as $N_{\text {ice }}$ as low as $10^{-4} \mathrm{~cm}^{-3}$.

correlations in Figure 9 and find remarkable similarities. In both IAGOS and research aircraft data sets, highest $\mathrm{N}_{\text {ice }}$ values are associated to highest $\mathrm{RH}_{\text {ice }}$ values, indicated by the dark blue coloured data points in Figure 12. Similar to the IAGOS observations shown in Figure 9, this feature is less pronounced at mid-latitudes in comparison to the subtropics and tropics. During ML-CIRRUS, the highest $\mathrm{N}_{\text {ice }}$ are dominated by contrails ${ }^{12}$.

Research aircraft data have been interpreted with respect to cirrus origin type ${ }^{12}$. The sub-set of clouds observed in the tropics at highest supersaturations of $145 \%$ and beyond and $\mathrm{N}_{\text {ice }}$ values above $1.0 \mathrm{~cm}^{-3}$ is characterised by a high ice water content well above $400 \mathrm{ppmv}$ and thus clearly of liquid origin. This conclusion can be drawn when relating the measurements presented in Figure 12 to the parameterisation of the ice water content presented by Krämer et al. ${ }^{11}$ and Luebke et al. ${ }^{12}$.

Concluding, our observations of high $\mathrm{N}_{\text {ice }}$ values at high $\mathrm{RH}_{\text {ice }}$ in the subtropics and tropics are confirmed by observations from research aircraft and can be considered of liquid origin cirrus as well. Besides this specific case, the firm attribution of cirrus origin to certain observations requires additional information, e.g. from trajectory analyses, which is not yet available for IAGOS data.

\section{Summary and Conclusions}

The European Research Infrastructure IAGOS (www.iagos.org) is conducting continuous in-situ measurements of atmospheric chemical composition $\left(\mathrm{O}_{3}, \mathrm{CO}, \mathrm{NO}_{x}, \mathrm{NO}_{y}, \mathrm{CO} 2, \mathrm{CH}_{4}\right)$, water vapour, aerosols and clouds on a global scale by operating compact instruments on board of passenger aircraft ${ }^{30}$. The emerging global scale data set on relative humidity with respect to ice $\left(\mathrm{RH}_{\text {ice }}\right)$ and cirrus cloud particle number concentration $\left(\mathrm{N}_{\text {ice }}\right)$ from 15 months of measurements has been analysed for the distributions of $\mathrm{RH}_{\text {ice }}$ in cirrus and in clear sky and for potential connections between $\mathrm{RH}_{\text {ice }}$ and $\mathrm{N}_{\text {ice. }}$ We split cirrus cloud observations into sub-sets of mid-latitude and subtropical to tropical observations and further divided them into observations over the Atlantic Ocean, the Eurasian 
Continent and the Pacific Ocean. Seasonal aspects were not tackled since the seasons are not equally represented in the data set.

The most important feature discovered in our data set is the finding that the distribution of $\mathrm{RH}_{\text {ice }}$ inside clouds shows a strong correlation to $\mathrm{N}_{\text {ice }}$ with higher dynamic equilibrium $\mathrm{RH}_{\text {ice }}$ values associated to higher $\mathrm{N}_{\text {ice }}$ values. On the other hand, the in-cloud distributions of $\mathrm{RH}_{\text {ice }}$ do not depend on the geographical regions of sampling.

We use the obtained information on the global frequency of occurrence of cirrus and on the vertical distribution of cloud occurrence and cloud properties with the discovered connection between $\mathrm{RH}_{\text {ice }}$ distributions in cirrus and respective $\mathrm{N}_{\text {ice }}$ values to further understand the formation processes and related properties of cirrus clouds in the global troposphere. Combining the vertical distribution of cloud observations (Figure 7), the distribution of $\mathrm{RH}_{\text {ice }}$ in clouds for three regimes of $\mathrm{N}_{\text {ice }}$ values (Figure 10), and the respective probabilities of occurrence in Table 2, the following sketch of cirrus types, properties and origin can be drawn:

For thin clouds with $\mathrm{N} \leq 0.1 \mathrm{~cm}^{3}$ in the subtropics and tropics, the $\mathrm{RH}_{\text {ice }}$ distribution is centred at $100 \%$ as expected for cirrus in thermodynamic equilibrium. For the same cloud type at mid-latitudes, however, the modal $\mathrm{RH}_{\text {ice }}$ value is shifted to approx. $105 \%$ which indicates the prevalence of considerable updrafts in cirrus. A similar shift of $\sim 10 \% \mathrm{RH}_{\text {ice }}$ of the modal value in clouds between mid-latitudes and subtropics to tropics is reported from combined CloudSat/CALIPSO analyses ${ }^{16}$. Cirrus with $\mathrm{N}_{\text {ice }} \leq 0.1 \mathrm{~cm}^{-3}$ are mostly associated with temperatures below approx. $220 \mathrm{~K}$ and may indicate in-situ origin cirrus in slow updrafts ${ }^{11}$. This predominant type of thin cirrus is observed in $67 \%$ (subtropical and tropical Pacific) to 90\% (mid-latitude continental) of all cases.

For cirrus with $0.1 \mathrm{~cm}^{3} \leq \mathrm{N}_{\text {ice }} \leq 1.0 \mathrm{~cm}^{3}$ the distribution of $\mathrm{RH}_{\text {ice }}$ becomes asymmetric and is centred at $105-110 \%$ with its larger part in ice-supersaturation, pointing at higher updrafts involved in the cloud formation in case of in-situ cirrus and sustained during cirrus evolution. We also found that high ice-supersaturation with $\mathrm{RH}_{\text {ice }}>120 \%$ is frequently associated with high $\mathrm{N}_{\text {ice }}$ values and temperatures above $220 \mathrm{~K}$. Warmer cirrus with $\mathrm{N}_{\text {ice }}>0.1 \mathrm{~cm}^{-3}$ in higher supersaturation indicates liquid origin cirrus in higher updrafts. Clouds of this type contribute between $10 \%$ (mid-latitude continental) and $28 \%$ (subtropical and tropical Pacific) of the observations.

Highest ice-supersaturations are observed for the cloud type with $\mathrm{N}_{\text {ice }}>1.0 \mathrm{~cm}^{-3} . \mathrm{RH}_{\text {ice }}$ can reach values as high as $150 \%$, notably in subtropical and tropical clouds. The occurrence of such high incloud supersaturation linked to high $\mathrm{N}_{\text {ice }}$ values (up to several tens per $\mathrm{cm}^{3}$ ) is most probably caused by quite strong updrafts due to convection. This interpretation is consistent with the hypothesis that these high $\mathrm{N}_{\text {ice }}$ values point to liquid origin anvil cirrus which are mostly linked to convective systems. The occurrence frequency of these very dense clouds ranges from less than $1 \%$ (mid-latitude continental) to $5 \%$ (subtropical and tropical Pacific). The observation of dense cirrus with $\mathrm{N}_{\text {ice }}>$ $1.0 \mathrm{~cm}^{-3}$ at temperatures below approx. $220 \mathrm{~K}$ at higher supersaturation points to in-situ cirrus formation in fast updrafts (gravity waves or jet streams) ${ }^{11}$, while a high number of $\mathrm{N}_{\text {ice }}$ around saturation or even at subsaturation indicates the presence of aviation-induced cirrus.

Current process-based cloud models for in-situ origin cirrus include the coupling of updraft velocities to detailed microphysics and $\mathrm{RH}_{\text {ice }}{ }^{11}$, whereas these features are not fully represented in global models, mainly because of different scales of model domains. For liquid origin cirrus, the 
investigation of these processes has just recently started and the representation in process as well as global models is to our knowledge not yet fully achieved.

The insight into cirrus distributions, properties and origin is supported by results from two recent field studies on cirrus at mid-latitudes (ML-CIRRUS) and in the tropics (ACRIDICON-CHUVA). Since the research aircraft was equipped with state-of-the-art instruments for measuring cirrus clouds and water vapour and the field studies have been accompanied by extensive modelling work, a detailed understanding of cirrus origin (in-situ origin and liquid origin) and associated cirrus properties was developed. However, the results are confined to a certain period of time and region.

The joint analysis of results from IAGOS and dedicated field studies adds the global scale to the detailed knowledge developed in the research campaigns. In that respect both approaches benefit each other. Similar concepts for linking IAGOS observations and dedicated field studies are conceivable for tackling open scientific questions in atmospheric chemistry. The continuously growing data set on atmospheric chemical composition data in general and $\mathrm{RH}_{\text {ice }}$ and $\mathrm{N}_{\text {ice }}$ in particular will allow the investigation of seasonal aspects of cirrus formation and properties and other research topics in atmospheric chemistry in the future.

\section{Acknowledgements}

IAGOS gratefully acknowledges financial support during its preparation, implementation and operation phase from the European Commission in FP6 and FP7 programmes, national research programmes in Germany (BMBF), France (INSU-CNRS, MESR, CNES) and UK (NERC), in addition to institutional resources in Germany (Helmholtz Association, Max-Planck-Society, Leibniz Association), France (Université de Toulouse, Météo-France) and the UK (University of Manchester, University of Cambridge), and the continuing support by participating airlines (Deutsche Lufthansa, Air-France, Iberia in Europe, China Airlines and Cathay Pacific in Asia).

\section{References}

1. O. Boucher, D. Randall, P. Artaxo, C. Bretherton, G. Feingold, P. Forster, V.-M. Kerminen, Y. Kondo, H. Liao, U. Lohmann, et al., in Climate Change 2013: The Physical Science Basis. Contribution of Working Group I to the Fifth Assessment Report of the Intergovernmental Panel on Climate Change, eds. T. F. Stocker, D. Qin, G.-K. Plattner, M. Tignor, S. K. Allen, J. Boschung, A. Nauels, Y. Xia, V. Bex and P. M. Midgley, Cambridge University Press, Cambridge, United Kingdom and New York, NY, USA, 2013.

2. M. Wendisch, P. Yang and P. Pilewskie, J. Geophys. Res.-Atmos., 2007, 112.

3. M. Wendisch, P. Pilewskie, J. Pommier, S. Howard, P. Yang, A. J. Heymsfield, C. G. Schmitt, D. Baumgardner and B. Mayer, J. Geophys. Res.-Atmos., 2005, 110.

4. F. Fusina, P. Spichtinger and U. Lohmann, J. Geophys. Res.-Atmos., 2007, 112.

5. A. Gettelman, X. Liu, D. Barahona, U. Lohmann and C. Chen, J. Geophys. Res.-Atmos., 2012, 117, D20201.

6. M. Riese, F. Ploeger, A. Rap, B. Vogel, P. Konopka, M. Dameris and P. Forster, J. Geophys. Res.-Atmos., 2012, 117, D16305.

7. R. Müller, A. Kunz, D. F. Hurst, C. Rolf, M. Krämer and M. Riese, Earth's Future, 2016, 4, 25-32.

8. E. A. Irvine and K. P. Shine, Earth Syst. Dynam., 2015, 6, 555-568.

9. T. Koop, B. P. Luo, A. Tsias and T. Peter, Nature, 2000, 406, 611-614.

10. C. Hoose and O. Möhler, Atmos. Chem. Phys., 2012, 12, 9817-9854.

11. M. Krämer, C. Rolf, A. Luebke, A. Afchine, N. Spelten, A. Costa, J. Meyer, M. Zöger, J. Smith, R. L. Herman, et al., Atmos. Chem. Phys., 2016, 16, 3463-3483. 
12. A. E. Luebke, A. Afchine, A. Costa, J. U. Grooss, J. Meyer, C. Rolf, N. Spelten, L. M. Avallone, D. Baumgardner and M. Krämer, Atmos. Chem. Phys., 2016, 16, 5793-5809.

13. H. Wernli, M. Boettcher, H. Joos, A. K. Miltenberger and P. Spichtinger, Geophys. Res. Lett., 2016, 43, 6657-6664.

14. K. Sassen, Z. Wang and D. Liu, J. Geophys. Res.-Atmos., 2008, 113, D00A12.

15. K. Sassen, Z. Wang and D. Liu, J. Geophys. Res.-Atmos., 2009, 114, D00h06.

16. B. H. Kahn, A. Gettelman, E. J. Fetzer, A. Eldering and C. K. Liang, J. Geophys. Res.-Atmos., 2009, 114, D00h02.

17. P. Spichtinger, K. Gierens and W. Read, Q. J. R. Meteorol. Soc., 2003, 129, 3391-3410.

18. A. Gettelman, E. J. Fetzer, A. Eldering and F. W. Irion, J. Climate, 2006, 19, 6089-6103.

19. N. Lamquin, C. J. Stubenrauch, K. Gierens, U. Burkhardt and H. Smit, Atmos. Chem. Phys., 2012, 12, 381-405.

20. K. Gierens, U. Schumann, M. Helten, H. Smit and A. Marenco, Ann. Geophys., 1999, 17, 12181226.

21. P. Spichtinger, K. Gierens, H. G. J. Smit, J. Ovarlez and J. F. Gayet, Atmos. Chem. Phys., 2004, 4, 639-647.

22. H. G. J. Smit, S. Rohs, P. Neis, D. Boulanger, M. Krämer, A. Wahner and A. Petzold, Atmos. Chem. Phys., 2014, 14, 13241-13255.

23. A. Zahn, E. Christner, P. F. J. van Velthoven, A. Rauthe-Schoech and C. A. M. Brenninkmeijer, J. Geophys. Res. Atmos., 2014, 119, 11505-11525.

24. J. Ovarlez, J. F. Gayet, K. Gierens, J. Ström, H. Ovarlez, F. Auriol, R. Busen and U. Schumann, Geophys. Res. Lett., 2002, 29, 1813.

25. M. H. Diao, M. A. Zondlo, A. J. Heymsfield and S. P. Beaton, Geophys. Res. Lett., 2014, 41, 4090-4099.

26. M. Diao, J. B. Jensen, L. L. Pan, C. R. Homeyer, S. Honomichl, J. F. Bresch and A. Bansemer, J. Geophys. Res.-Atmos., 2015, 120, 5101-5121.

27. M. Krämer, C. Schiller, A. Afchine, R. Bauer, I. Gensch, A. Mangold, S. Schlicht, N. Spelten, N. Sitnikov, S. Borrmann, et al., Atmos. Chem. Phys., 2009, 9, 3505-3522.

28. A. E. Luebke, L. M. Avallone, C. Schiller, J. Meyer, C. Rolf and M. Krämer, Atmos. Chem. Phys., 2013, 13, 6447-6459.

29. A. Marenco, V. Thouret, P. Nédélec, H. Smit, M. Helten, D. Kley, F. Karcher, P. Simon, K. Law, J. Pyle, et al., J. Geophys. Res., 1998, 103, 25631-25642.

30. A. Petzold, V. Thouret, C. Gerbig, A. Zahn, C. A. M. Brenninkmeijer, M. Gallagher, M. Hermann, M. Pontaud, H. Ziereis, D. Boulanger, et al., Tellus B, 2015, 67, 28452.

31. K. Gierens and P. Spichtinger, Ann. Geophys., 2000, 18, 499-504.

32. K. Beswick, D. Baumgardner, M. Gallagher, A. Volz-Thomas, P. Nédélec, K. Y. Wang and S. Lance, Atmos. Meas. Tech., 2014, 7, 1443-1457.

33. K. Beswick, D. Baumgardner, M. Gallagher, G. B. Raga, P. Minnis, D. A. Spangenberg, A. VolzThomas, P. Nédélec and K.-Y. Wang, Tellus B, 2015, 67, 27876.

34. P. Neis, H. G. J. Smit, S. Rohs, U. Bundke, M. Krämer, N. Spelten, V. Ebert, B. Buchholz, K. Thomas and A. Petzold, Tellus B, 2015, 67, 28320.

35. M. Helten, H. G. J. Smit, W. Strater, D. Kley, P. Nédélec, M. Zoger and R. Busen, J. Geophys. Res., 1998, 103, 25643-25652.

36. P. Neis, H. G. J. Smit, M. Krämer, N. Spelten and A. Petzold, Atmos. Meas. Tech., 2015, 8, 1233-1243.

37. D. Sonntag, Meteorol. Z., 1994, N.F. 3, 51-66.

38. D. P. Dee, S. M. Uppala, A. J. Simmons, P. Berrisford, P. Poli, S. Kobayashi, U. Andrae, M. A. Balmaseda, G. Balsamo, P. Bauer, et al., Q. J. R. Meteorol. Soc., 2011, 137, 553-597.

39. A. Kunz, N. Spelten, P. Konopka, R. Mueller, R. M. Forbes and H. Wernli, Atmos. Chem. Phys., 2014, 14, 10803-10822.

40. T. Reichler, M. Dameris and R. Sausen, Geophys. Res. Lett., 2003, 30.

41. H. G. J. Smit, A. Volz-Thomas, M. Helten, W. Paetz and D. Kley, J. Atmos. Oceanic Technol., 2008, 25, 656-666. 
42. C. Voigt, U. Schumann, A. Minikin, A. Abdelmonem, A. Afchine, S. Borrmann, M. Boettcher, B. Buchholz, L. Bugliaro, A. Costa, et al., Bull. Am. Met. Soc., 2016, 0, null.

43. M. Wendisch, U. Pöschl, M. O. Andreae, L. A. T. Machado, R. Albrecht, H. Schlager, D. Rosenfeld, S. T. Martin, A. Abdelmonem, A. Afchine, et al., Bull. Am. Met. Soc., 2016, 97, 1885-1908.

44. P. Spichtinger, K. Gierens and W. Read, Meteorol. Z., 2002, 11, 83-88.

45. P. Spichtinger and K. M. Gierens, Atmos. Chem. Phys., 2009, 9, 2319-2334.

46. P. Spichtinger, Tellus A, 2014, 66.

47. F. Schröder, B. Kärcher, C. Duroure, J. Ström, A. Petzold, J. F. Gayet, B. Strauss, P. Wendling and S. Borrmann, J. Atmos. Sci., 2000, 57, 464-480.

48. U. Schumann, R. Baumann, D. Baumgardner, S. T. Bedka, D. P. Duda, V. Freudenthaler, J. F. Gayet, A. J. Heymsfield, P. Minnis, M. Quante, et al., Atmos. Chem. Phys., 2017, 17, 403-438.

49. B. Buchholz, A. Afchine, A. Klein, C. Schiller, M. Krämer and V. Ebert, Atmos. Meas. Tech., 2017, 10, 35-57.

50. J. Meyer, C. Rolf, C. Schiller, S. Rohs, N. Spelten, A. Afchine, M. Zöger, N. Sitnikov, T. D. Thornberry, A. W. Rollins, et al., Atmos. Chem. Phys., 2015, 15, 8521-8538. 